\title{
Commitment and Release Standards and Procedures: Uniform Treatment for the Mentally Ill
}

Significant variations exist among statutory provisions for the involuntary commitment and release of persons found incompetent to stand criminal trial, ${ }^{1}$ persons found not guilty of a criminal offense by reason of insanity, ${ }^{2}$ mentally ill criminals, ${ }^{3}$ and persons committed in civil proceedings. ${ }^{4}$ These variations in commitment and release standards and procedures are critical because they may involve indefinite loss of an individual's freedom without adequate safeguards.

Courts $^{5}$ and commentators ${ }^{\theta}$ have established that the states must provide certain protections for the civilly committed under the due process clause of the fourteenth amendment. This comment examines the justifications for differential treatment of the other three subgroups based on their involvement in the criminal process and concludes that

1 An individual is not required to stand trial if he cannot "understand the nature and object of the proceedings against him, comprehend his own condition in reference to such proceedings, and assist in his defense." Hess, Pearsall, Slichter, \& Thomas, Competency to Stand Trial, in Readings In LAw \& Psychiatry 379 (R. Allen, E. Ferster \& J. Rubin eds. 1968). Most jurisdictions retain this common law test of incompetency. American Bar foundation, The Mentally Disabled and the Law 410 (rev. ed. S. Brakel \& R. Rock 1971) [hereinafter cited as ABF STUDY].

2 Acquittal by reason of insanity "reflects a jury determination, beyond a reasonable doubt, that except for the defense of insanity, defendant did do the act, . . . and have the intent, that constitutes the substantive crime without any exculpation or mitigation in non-insanity defenses. . . ." Dixon v. Jacobs, 427 F.2d 589, 601 (D.C. Cir. 1970) (Leventhal, J., concurring in part). The defendant, however, lacks sufficient responsibility for the act to be subjected to the sanctions of the criminal law. See ABF STUDY, supra note I, at 376-79.

3 Mentally ill criminals include sexual psychopaths, defective delinquents, and persons who are convicted of crimes and later determined to be mentally ill.

4 Civil commitment or involuntary hospitalization is provided for in all states by some method, and in most states by judicial proceedings. ABF STUDY, supra note 1, at 15 Table 1.1.

5 See, e.g., In re Ballay, 482 F.2d 648 (D.C. Cir. 1973) (fifth amendment due process claim); Heryford v. Parker, 396 F.2d 393 (10th Cir. 1968); Lessard v. Schmidt, 349 F. Supp. 1078 (E.D. Wis. 1972) (three-judge court), vacated and remanded on other grounds, 94 S. Ct. 713 (1974); Holm v. State, 404 P.2d 740 (Wyo. 1965).

6 See, e.g., Kutner, The Illusion of Due Process in Commitment Proceedings, 57 Nw. U.L. REv. 383 (1962); Developments in the Law-Civil Commitment of the Mentally Ill, 87 HARv. L. REv. 1190 (1974) [hereinafter cited as Developments in the Law]; Comment, Due Process for All-Constitutional Standards for Involuntary Civil Commitment and Release, 34 U. Chr. L. REv. 633 (1967) [hereinafter cited as Due Process for All]. 
the equal protection guarantee generally requires identical statutory protection for these other subgroups. Even more effective protection than that provided by statute for the civilly committed may be required in states where the statutory protection is deficient under due process analysis.

\section{Grvil Commitment: Due Process Protections}

Involuntary civil commitment involves a substantial deprivation of liberty during confinement; freedoms of association, privacy and travel are severely restricted. ${ }^{7}$ After release, the former mental patient may also be deprived of various rights and privileges, including the right to vote $^{8}$ and the privilege of obtaining a driver's license. ${ }^{9}$ These deprivations may be accomplished by the state only after the individual has been afforded the protections of due process, but the degree, form, and timing of the required protections depend on a balancing of the individual's interest in maintaining his liberty against the state's interest in depriving him of it. ${ }^{10}$ Most cases applying this balancing test have required a relatively high degree of due process protection for the civilly committed.11

\section{A. Commitment Standards and Procedures}

Two interests of the state may be served by involuntary commitment: treatment of mentally ill citizens unable to care for themselves, ${ }^{12}$ grounded in the state's parens patriae power; $;^{13}$ and protection of the public from potentially dangerous mentally ill persons, ${ }^{14}$ grounded in

$\tau$ Besides the restrictions inherent in involuntary confinement, the patient's rights may be infringed by restrictions on communication, by intrusive treatment methods, and by required work with insufficient compensation. See ABF STUDY, supra note 1, at 155-71; See also 86 HARv. L. REv. 1282, 1287 (1973).

8 See, e.g., Det. CODE ANN. tit. 15, § 1701 (Supp. 1970); Ky. Rev. STAT. $\$ 202.272$ (1972).

9 See, e.g., FuA. Stat. ANN. \$ 322.05 (1968); N.Y. Veh. \& Traf. Law \$ 510.3(b) (McKinney 1970); cf. Bell v. Burson, 402 U.S. 535, 539 (1971) (denial of a driver's license is subject to due process protections).

10 See Morrissey v. Brewer, 408 U.S. 471, 481 (1972).

11 See generally Developments in the Law, supra note 6.

12 This interest is typically expressed as the "in need of care or treatment" standard. See, e.g., ILL. REv. STAT. ch. 911/2, § 1-11 (1973); Iowa Code ANN. § 225.10 (Supp. 1974).

13 See Developments in the Law, supra note 6, at 1207-09.

14 This interest is typically embodied in a statutory "dangerous to self or others" standard. See, e.g., Ixc. REv. Stat. ch. 911/2, § 1-11 (1973); N.H. REv. STAT. ANN. § 135-B:26 (Supp. 1973). Commitment for dangerousness to self is justified under the parens patriae power rather than the police power. Developments in the Law, supra note 6, at 1223-28; Note, Civil Commitment of the Mentally Ilt: Theories and Procedures, 79 HARv. L. REv. 1288, 1293 (1966) [hereinafter cited as Theories and Procedures]. In this comment, "dangerousness" will be used to refer to the police power commitment standard. 
the state's police power. The parens patriae power justifies involuntary commitment only when the mentally ill individual is unable to decide to seek treatment himself. In that case, the individual's and the state's interests in commitment for treatment coincide. ${ }^{15}$ The protection interest justifies involuntary commitment if it can be predicted with a sufficient degree of certainty that the individual may inflict substantial harm upon others. ${ }^{16}$ The state's interest in preventing the infliction of that harm would then override the individual's interest in maintaining his liberty. ${ }^{17}$

The procedural protections required by the due process guarantee for persons whose involuntary civil commitment is thus justified ${ }^{18}$ are determined through the same balancing test. Although the state may have an additional interest in minimizing the costs of commitment procedures, there is a societal and an individual interest in procedures that optimally limit commitments to those justified under the incapacity or predicted dangerousness standards, avoiding both underinclusive and overinclusive commitment procedures.

Notice of the proceedings ${ }^{10}$ and an opportunity to be heard ${ }^{20}$ before commitment promote the accuracy of the commitment determination.

16 When a competent individual resists commitment, his interest in liberty outweighs the substantially weaker state interest in substituting its judgment for the individual's and providing treatment for deviant but nondangerous manifestations of his illness. $C f$. Due Process for All, supra note 6, at 653-54. See generally Developments in the Law, supre note 6 , at 1209-22.

16 The degree of likelihood of harm that would be sufficient to justify preventive confinement is difficult to determine without reference to the magnitude of the potential harm and without a more precise science of behavioral prediction. See Cross v. Harris, 418 F.2d 1095, 1100 (D.C. Cir. 1969); Developments in the Law, supra note 6, at 1286-45.

17. The trend in legislative and judicial standards seems to be towards a dangerousness standard alone, and towards a higher standard of dangerousness in the form of "a recent overt act, attempt or threat" requirement upon which the dangerousness prediction must be based. Lessard v. Schmidt, 349 F. Supp. 1078, 1093 (E.D. Wis. 1972), vacated and remanded on other grounds, 94 S. Ct. 713 (1974); cf. Jackson v. Indiana, 406 U.S. 715, 728 (1972). See, e.g., CAL. WeLF, \& Inst'NS CODE $\$ 5300$ (West 1972); Mass. Gen. LAws ANN. ch. 123, §\& 1 \& 8 (Supp. 1972). See also Developments in the Law, supra note 6, at 1205-06.

18 It should be noted that confinement for a very short period for the limited purpose of a prehearing examination is necessary in most involuntary commitment situations and is justified by an interest in assuring the accuracy of the threshold determination of mental illness. See, e.g., D.C. CODE ANN. \& $21-528$ (1973); Mo. ANN. STAT. \& 202.805(3) (1972). See also note 26 infra. In cases involving criminal offenses, this specialized confinement may be for a longer period, see text and notes at notes 59, 64 \& 81-82 infra, but indefinite confinement can be justified only by the standards discussed in the text.

19 See, e.g., ARtz. Rev. Stat. ANN. \& 36-513 (Supp. 1973) (notice unless harmful); ILL. REv. Stat. ch. 911/2, \$\$ 8-7 (1973) (mandatory notice); IND. ANN. Stat: § 22-1216 (1964) (same).

20 See, e.g., Ir.. REv. STAT. ch. 911/2, \$\& 8-7 (1973) (immediate mandatory hearing); WIS. STAT. \$ 51.04(1)-(3) (1957) (delayed hearing). Every state with a judicial commitment procedure either requires or allows a hearing. ABF STUDY, supra note 1, at 80 Table 3.3. 
These procedural safeguards are fundamental in criminal trials, ${ }^{21}$ which involve a balancing of substantially similar interests: ${ }^{22}$ protection of society, maintenance of the defendant's freedom, and optimal accuracy of guilt determination. Thus, by analogy, the explicit constitutional safeguards for criminal defendants are strong support for similar safeguards for those civilly committed under the dangerousness standard. ${ }^{23}$

Notice and a precommitment hearing may justifiably be denied, however, in dangerousness commitments involving an emergency situation, ${ }^{24}$ or in incapacity commitments of individuals for whom the precommitment hearing experience would be peculiarly traumatizing. ${ }^{25}$ In emergency situations, the additional state interest in expeditious removal of the immediately dangerous individual from society may justify prehearing confinement, ${ }^{26}$ although due process would require a full hearing before indefinite commitment. ${ }^{27}$ When the denial of procedural safeguards is based on the traumatizing effects of a formal hearing, the justification is that the individual's interests coincide with those of the state against procedural protections. Although the justifica-

21 In re Oliver, 333 U.S. 257, 273 (1948).

22 Lessard v. Schmidt, 349 F. Supp. 1078, 1084 (E.D. Wis. 1972), vacated and remanded on other grounds, $94 \mathrm{~S}$. Ct. 713 (1974). In a civil commitment for dangerousness, a determination of future dangerousness as well as of prior behavior must be made, and the justification for a fact finding hearing is even stronger.

23 In re Ballay, 482 F.2d 648, 657-58 (D.C. Cir. 1973); Lessard v. Schmidt, 349 F. Supp. 1078, 1084 (E.D. Wis. 1972); Denton v. Commonwealth, 383 S.W.2d 681 (Ky. 1964); Holm v. State, 404 P.2d 740 (Wyo. 1965); cf. In re Gault, 387 U.S. 1, 36 (1967).

24 See, e.g., GA. CODE \& 88-504.4 (1971); Irx. Rev. STAT. ch. 911/2, \& 7-6 (1973). Almost all states provide for emergency detention for short periods, and over one-half of those with emergency detention provisions require clear and present or immediate danger. ABF STUDY, supra note 1, at 43, 118 Table 3.11; Developments in the Law, supra note 6, at $1204-05$.

25 See, e.g., Iowa Code ANN. \& 229.4 (1969); N.J. STAT. ANN \& 30:4-11 (Supp. 1974). See Kutner, supra note 6, at 392-94. This exception to procedural protections, however, presupposes an illness of a certain type, the existence of which must be determined at the hearing itself in states without a prehearing medical diagnosis procedure. See In re Ballay, 482 F.2d 648, 664 (D.C. Cir. 1973); ABF STUDY, supra note 1, at 50, 72 Table 3.2. The traumatic effects of commitment upon one who is wrongly committed because of abbreviated procedural protections should also weigh heavily against this limited exception. See generally E. Gorrman, AsYlums (1961).

26 The situation is somewhat analogous to criminal pretrial detention. For a proposal for provision of an abbreviated preliminary hearing within forty-eight hours of emergency commitment, see Developments in the Law, supra note 6, at 1276-79.

$2 \pi$ The interest in optimal accuracy of commitment determinations produced by the serious deprivations involved in long-term confinement require a hearing before that confinement is justified. Cf. In re Coates, 9 N.Y.2d 242, 213 N.Y.S.2d 74, 173 N.E.2d 797 (1961), appeal dismissed sub nom. Coates v. Walters, 368 U.S. 34 (1961), where notice was xequired to allow challenge before an indefinite extension of commitment, even though the initial short-term commitment procedures were justifiably abbreviated. 
tion is valid to the extent that a peculiar sensitivity is found in the threshold medical examination, ${ }^{28}$ it should not preclude a modified hearing procedure or notice prior to indefinite deprivation of the individual's liberty. ${ }^{29}$

The right to be represented by counsel at commitment hearings is provided by statute in every state, and a majority of states also provide for appointment of counsel for indigents. ${ }^{30}$ Under due process requirements, a concurrent interest of individual and state in adequate representation of the mentally ill individual and optimal accuracy of the commitment determination outweigh the additional costs to the state and the potential delay inherent in these provisions. ${ }^{31}$

Due process also requires that the necessity of commitment be proved beyond a reasonable doubt. ${ }^{32}$ The serious deprivations that accompany commitment justify the higher expenditures by the state that may be necessary to carry this more stringent burden of proof. ${ }^{33}$

The right to a jury in a civil commitment proceeding ${ }^{34}$ is important to the protection of the individual's interests because the "representative community judgment" of the jury decreases the probability of arbitrary deprivations of liberty. ${ }^{35}$ The exercise of a community judgment is more important in commitment proceedings than in criminal trials because commitment standards are not as specific as criminal statutes in describing the behavior that justifies deprivation of liberty.$^{36}$

28 See note 25 supra.

29 See, e.g., InI. REv. STAT. ch. 911/2, § 9-4 (1973), which allows informal conference with the judge or jury. This provides the necessary nonmedical component of the determination of satisfaction of the commitment standards. See Humphrey v. Cady, 405 U.S. 504, 509 (1972); ABF STUDY, supra note 1, at 54.

80 ABF STudy, supra note I, at 54. See, e.g., ILL. REv. STAT. ch. 911/2, § 9-4 (1973) (appointed counsel); ME. REv. Stat. ANN. tit. 34 § 2334 (Supp. 1973); MD. ANN. Code art. 59, § 54 (Supp. 1973) (appointed counsel); N.H. REv. STAT. ANN. § 135-B:5-6 (Supp. 1973) (same).

81 Heryford v. Parker, 396 F.2d 393, 396 (10th Cir. I968); Lessard v. Schmidt, 349 F. Supp. 1078, 1097-1100 (E.D. Wis. 1972), vacated and remanded on other grounds, 94 S. Ct. 713 (1974); cf. Argersinger v. Hamlin, 407 U.S. 25 (1972) (right to counsel in misdemeanor cases determined by possibility of imprisonment for six months or more).

82 In re Ballay, 482 F.2d 648, 662-67 (D.C. Cir. 1973); Lessard v. Schmidt, 349 F. Supp. 1078, 1095 (E.D. Wis. 1972); In re Pickles' Petition, 170 So.2d 603, 614 (Fla. Ct. App. 1965); Denton v. Commonwealth, 383 S.W.2d 681, 683 (Ky. 1964); Ex parte Perry, 137 N.J.Eq. 161, 43 A.2d 885 (Ch. 1945); cf. In re Winship, 397 U.S. 358 (1970).

33 But see Developments in the Law, supra note 6, at 1297-1303. If commitment standards require too high a degree of precision in the proof of future dangerousness, the increased probability of underinclusiveness might justify a lower burden of proof.

34 See, e.g., IrL. REv. STAт. ch. 911/2 § 9-2 (1973) (at patient's request); OrLA. Star. ANN. tit. 43A. \& 55 (Supp. 1973) (at request of certain persons or in court's discretion). But see OHro Rev. Code ANn. \$ 5122.15 (Page 1970) (no jury permitted).

85 See Duncan v. Louisiana, 391 U.S. 145 (1968) (role of jury in criminal proceedings). 86 See ABF STUDY, supra note 1, at 54; cf. Humphrey v. Cady, 405 U.S. 504, 509 (1972). 
The state's concern with efficient procedures does not justify denying this right to an individual who seeks to maintain his liberty. ${ }^{37}$

\section{B. Release Standards and Procedures}

The continuation of confinement beyond a period reasonably related to the purpose of the original commitment may be justified only by state interests that significantly outweigh the individual's interest in regaining his liberty. ${ }^{38}$ Release standards should therefore require the absence of the condition that satisfied the original commitment standard, ${ }^{39}$ rather than a finding of general improvement or of "regained sanity." 40

The inconsistency in many statutory schemes ${ }^{41}$ between standards used to initiate involuntary civil commitment and standards used to terminate it may be further aggravated by release procedures that allow the termination decision to be made by medical authorities alone. ${ }^{42}$ Under these procedures, the nonmedical aspect of the original commitment decision ${ }^{43}$ may be ignored or determined by an improper representative of the community.

States that permit judicial release by petition ${ }^{44}$ or by writ of habeas corpus $^{45}$ under properly defined release standards seem to satisfy due process requirements. But the holdings of the Supreme Court in Jackson v. Indiana ${ }^{46}$ and McNeil v. Director, Patuxent Institution ${ }^{47}$-that confinement beyond a period reasonably necessary to accomplish the purposes of commitment is unconstitutional unless justified anew-im-

37 The cases that have required jury trials in civil commitment proceedings have been in jurisdictions where the right is provided by statute, but the reasoning of the cases would support an independent due process argument for the right. See, e.g., Quesnell v. State, 83 Wash. 2d 224, 517 P.2d 568, 578-79 (1973). But see McKeiver v. Pennsylvania, 403 U.S. 528 (1971); Developments in the Law, supra note 6, at 1291-95.

38 See Jackson v. Indiana, 405 U.S. 715, 738 (1972) (commitment of persons found incompetent to stand trial justified only as long as reasonably related to purpose of commitment).

39 See, e.g., Alaska Stat. § 47.30 .220 (1971); Aruz. Rev. Stat. ANN. § 36-524 D (Supp. 1973).

40 See, e.g., S.D. COMPILED LAws ANN. § 27-10-2 (1967).

41 Compare, e.g., Ill. Rev. Stat. ch. 911/2, § 1-11 (1973), with Il.. Rev. Stat. ch. 911/2, § 10-4 (1973), allowing discharge by administrators under regulations promulgated by the Department of Mental Health, without requiring the reapplication of commitment standards.

42 See, e.g., InL. Rev. Stat. ch. 911/2, § 10-4 (1973); Kan. Stat. ANN. § 59-2924 (Supp. 1973). See ABE Studx, supra note 1 , at $136-40$.

43 See notes 29, 35-37 supra.

44 See, e.g., In. Rev. STAT. ch. 911/2, § 10-2 (1973); WYo. Stat. ANN. § $25-68$ (1967).

45 See, e.g., Inx. Rev. Stat. ch. 911/2, \$ 10-6 (1973); Iowa Code \$ 229.37 (1969).

46406 U.S. 715 (1972).

47407 U.S. 245 (1972). 
ply the need for mandatory review of an individual's condition at the end of the initial commitment period. ${ }^{48}$ Since this review would be essentially a recommitment proceeding, the specific procedural protections required in the original commitment must be provided in the subsequent proceeding. ${ }^{49}$

\section{Commitment During the Criminal Process: Due Process and Equal Protection}

The equal protection guarantee requires that statutory discrimination among subgroups of the involuntarily committed be rationally related to legitimate state purposes. ${ }^{50}$ Members of the four subgroups considered in this comment must in general be afforded the same statutory protections, since commitment serves substantially identical state purposes for each subgroup. Furthermore, the balancing of state purposes against individual interests for each subgroup requires a degree of due process protection equivalent to that required for the civilly committed, even though this due process protection may exceed statutory protection of the civilly committed provided by some states. ${ }^{\text {51 }}$

Involvement in the criminal process, even through conviction, is an inadequate justification for differential standards and procedures in commitment. ${ }^{2}$ The purposes served by penal incarceration are protec-

48 Mandatory review would also be required at the end of each subsequent period. Several states provide for-this periodic review of the individual's status. See, e.g., InL. Rev. STAT. ch. 911/2, \& 10-2 (1973); WYo. StaT. ANN. \& 25-68 (1967).

19 The potentially traumatizing effect of notice and formal judicial hearing may be more easily discovered after an initial period of extended observation and diagnosis, and dispensing with those precedural protections may thus be justified. But the right to be represented by appointed counsel at a hearing, the right to obtain outside psychiatric testimony, and the other procedural protections are essential to the adequate presentation of the individual's case for release. See ABF STUDY, supra note 1, at 141. The burden on the state of providing periodic review with a full hearing is lightened by the potential for avoiding the cost of unnecessarily prolonged confinement and treatment and may be directly reduced by setting the date for subsequent release hearings on the basis of the best estimate of the time over which the individual's condition is likely to change. See Developments in the Law, supra note 6, at 1392-94.

50 Although the fundamental interest of liberty would seem to trigger the strict scrutiny test, the Supreme Court has consistently used the rational relationship test to examine the constitutionality of mental health laws. See Baxstrom v. Herold, 383 U.S. 107, 111 (1966); Comment, Commitment Following Acquittal by Reason of Insanity and the Equal Protection of the Laws, 116 U. PA. L. REv. 924-34 (1968) [hereinafter cited as Commitment Following Acquittal].

51 See, e.g., ALA. CoDE tit. 45, §§ 189-230 (Supp. 1973) (no notice provided); OHo REv. Code ANN. \& 5122.15 (Page 1970) (jury prohibited).

52 Jackson v. Indiana, 406 U.S. 715, 724 (1972); Humphrey v. Cady, 405 U.S. 504, 510-11 (1972); Baxstrom v. Herold, 383 U.S. 107, 111-12 (1966); cf. McNeil v. Director, Patuxent Institution, 407 U.S. 245, 249 (1972). 
tion of society by removal of the individual for a certain time, rehabilitation of the individual, retribution, and deterrence. ${ }^{53}$ The first two purposes are essentially equivalent to the state interests justifying civil commitment. ${ }^{54}$ The latter two-retribution and deterrence-are inapplicable to mentally ill individuals who are committed in the course of the criminal process. Even if retribution is still a legitimate purpose of punishment for convicted criminals, ${ }^{55}$ it is an inappropriate purpose of punishment for mentally ill criminals who lack full volitional capacity ${ }^{56}$ And confinement of a mentally ill individual who has been charged with or convicted of a crime is unlikely to deter either the individual ${ }^{57}$ or others ${ }^{58}$ from committing similar crimes. Thus, since no additional legitimate state purposes are served by the commitment of mentally ill persons involved in the criminal process, the equal protection clause requires substantially equivalent statutory protection for persons committed in criminal proceedings as for persons civilly committed. Some minor differentiation, however, is permissible. The most important instance of such differentiation is shortterm prehearing confinement, which may be justified for specific purposes peculiar to each group..$^{59}$

\section{A. The Incompetent to Stand Trial}

In some states, persons found incompetent to stand criminal trial have run the risk of indefinite commitment without further proceedings on the commitment issue..$^{6 \circ}$ The Supreme Court held in Jackson

53 United States v. Brown, 381 U.S. 437, 458 (1965); In re Ballay, 482 F.2d 648, 657 (D.C. Cir. 1973); see W. LAFave \& A. Scotr, Griminal Law 22-24 (1972).

54 For a mentally healthy criminal, of course, these two purposes are among a composite of purposes that underlies the criminal law generally, and imprisonment need not be justified by the actual existence of either. Civil commitment, on the other hand, must be justified by a finding of actual need for either treatment or protection of society.

55 Although the theory persists, it has long been disfavored by the courts. See Williams v. New York, 337 U.S. 241, 248 (1949).

56 State v. Carter, 15 Crim. L. Rep. 2050 (N.J. Sup. Ct., April 17, 1974); W. LaFave \&e A. Scotr, supra note 53, at 272; see Modet PeNal Code \$ 4.01, Comment (Tent. Draft No. 4, 1955).

57 W. LAFave \& A. ScotT, supra note 53, at 271; Theories and Procedures, supra note 14 , at 1290.

58 General deterrence operates on the assumption that potential rule-breakers identify themselves with the punished individual, and this is unlikely to occur when the involuntarily committed person is mentally ill. See ABF SruDY, supra note 1, at 377; W. LAFave \& A. ScotT, supra note 53, at 271-72.

59 See note 18 supra. Although different conditions in each of the four subgroups provide different bases for prehearing confinement of varying duration, ultimate commitment in all four must be accomplished within the limitations of the due process balancing test.

60 See, e.g., LA. Code Crim. Pro. ANn. \& 648 (West 1967). 
v. Indiana, ${ }^{, 1}$ however, that these schemes violate the equal protection clause when it is easier for such persons to be committed and more difficult for them to obtain release than for their civilly committed mentally ill or mentally retarded counterparts. ${ }^{62}$ The Court held that standards for commitment beyond a period necessary to determine by examination whether an individual would soon become competent to stand trial must be identical with the standards applied in ordinary civil commitment. ${ }^{63}$ Other than its interest in helping the individual become competent to stand trial, for which a confinement of determinate length and specific narrow purpose can be justified, ${ }^{\text {,4 }}$ the state's purposes in committing these individuals do not differ sufficiently from those that justify civil commitment to permit a difference in commitment standards. ${ }^{65}$ The fact that a person has been charged with a crime does not in itself satisfy the dangerousness standard, and the finding of incompetency is insufficient to satisfy the "in need of care" standard.

The Court also struck down a statutory release standard that provided for release and trial only after the individual had "become sane," since the release standard under civil commitment was more lenient. ${ }^{68}$ The state's purpose in continuing the confinement of an individual who would never become competent to stand trial and yet would meet the release standards if he had been civilly committed was not sufficiently different from its purpose in civil commitment to justify the stricter release standard, even though the individual had been charged with a criminal act.

The equal protection clause also requires identical commitment and release procedures for the incompetent to stand trial and the civilly committed. ${ }^{67}$ There is no justification for different procedural protections in determining whether civil commitment standards are satisfied in committing a person found incompetent to stand trial.

Due process considerations, independent of this equal protection analysis, require this higher level of protection for the incompetent to stand trial, even if the state's civil commitment statutes are deficient

\footnotetext{
61406 U.S. 715 (1972).

62 Id. at 730.

63 Id. at 738.

64 See note 18 supra. This preliminary confinement would consist of a short observation period, followed by a treatment period if the individual would reach competency "soon." 406 U.S. at 738.

65406 U.S. at 728.

66 Id. at 728-30.

07 This issue was not closely examined by the Court in Jackson. A full hearing (though without a jury) was provided by statute for incompetency commitments as well as for civil commitment. Id. at 720-21, 727. Release procedures were not considered.
} 
under the due process analysis discussed earlier. ${ }^{68}$ The state's interests in indefinite commitment of mentally ill persons are the same for the incompetent to stand trial and the civilly committed, despite the alleged commission of a criminal act by members of the former subgroup. Although evidence of the alleged act may be relevant to issues of predicted dangerousness and incapacity, it is not dispositive of either issue. ${ }^{69}$ Thus, under a due process balancing test, the interests of the individual in maintaining his liberty, and of both the state and the individual in accuracy of commitment and release determinations require the same procedural safeguards for the civilly committed and the incompetent to stand trial.

\section{B. The Not Guilty by Reason of Insanity}

The rationale for acquittal by reason of insanity is that the defendant, unlike other criminals, lacks sufficient responsibility for his act to be punished. ${ }^{70}$ The state may not and will not use punishment against such a defendant for its deterrent or retributive effects, and its interests are again identical with those underlying involuntary civil commitment. ${ }^{71}$ In some states, however, persons acquitted under these circumstances are subject to an unjustified deviation from civil commitment standards. Several states allow summary commitment following these acquittals, either without a hearing or on the ex parte determination of a judge that the individual is currently insane. ${ }^{72}$ Several state courts $^{73}$ have upheld abbreviated procedures against equal protection attacks on the basis of a "special interest" that arises upon a judicial determination that the individual has committed a criminal act as a result of his mental condition. ${ }^{74}$ Other courts, however, have recognized that this "special interest" does not justify major differences between commitment standards or procedures provided for the not

68 See text and notes at notes $7-49$ supra.

69406 U.S. at 736. The justification for deprivation of the individual's liberty remains the same, and satisfaction of the commitment standards must be proved by supplementary evidence.

70 See ABF STUDY, supra note 1, at 376-84; text and note at note 56 supra.

71 For the same reasons, an argument that no deprivation of liberty occurs through commitment of persons acquitted by reason of insanity because the alternative is imprisonment fails. The verdict of acquittal implies a lack of culpability, and commitment must be justified by proved dangerousness or need for care.

72 See, e.g., Ala. Code tit. 15, § 429 (1958); MrnN. Stat. AnN. § 631.19 (Supp. 1974). See also ABF STudx, supra note 1, at 430 Table 11.1.

73 In re Franklin, 7 Cal. 3d 126, 496 P.2d 465, 101 Cal. Rptr. 553 (1972); Chase v. Kearns, 278 A.2d 132 (Me. 1971); cf. Mills v. State, 256 A.2d 752 (Del. 1968) (due process claim denied).

74 Chase v. Kearns, 278 A.2d 132, 138 (Me. 1971). 
guilty by reason of insanity and those provided for the civilly committed.75

The "special interest" argument for differential standards and procedures is based upon presumptions drawn from the findings of mental illness and dangerousness implicit in the not guilty by reason of insanity verdict. These presumptions, however, are not always valid. Although the defendant may have been mentally ill or retarded at the time of the crime, commitment must be justified by a present mental illness. ${ }^{76} \mathrm{~A}$ presumption of continued insanity may be valid in a majority of cases; ${ }^{77}$ but it may be invalid, for example, when the crime was provoked by an extraordinary stimulus or when spontaneous recovery or substantial improvement is possible between commission of the crime and completion of the trial. ${ }^{28}$ The presumption of dangerousness is also invalid. Some criminal acts, although proscribed by society in its criminal laws, do not constitute substantial enough harm to persons or property to justify commitments based upon the police power. ${ }^{79}$ Even if the criminal act is dangerous or injurious in itself, the state cannot justify confinement in absence of its deterrent and retributive interests without a prediction of the likelihood of future dangerousness. That prediction does not necessarily follow from past commission of a criminal act. 80

Evidence of the crime, however, is relevant to the determination of dangerousness since it may indicate a greater likelihood of future harmful acts. The period of prehearing confinement for observation and examination may justifiably be longer due to this higher potential for dangerousness. ${ }^{81}$ But no justification exists for the willingness of some courts to allow prehearing confinement of long duration..$^{82}$ An immedi-

75 See, e.g., Bolton v. Harris, 395 F.2d 642 (D.C. Cir. 1968); People v. Lally, 19 N.Y.2d 27, 277 N.Y.S.2d 654, 244 N.E.2d 87 (1966); Commonwealth ex rel. DiEmilio v. Shovlin, 449 Pa. 177, 295 A.2d 320 (1970).

70 Bolton v. Harris, 395 F.2d 642, 646 (D.C. Cir. 1968).

77 See In re Franklin, 7 Cal. $3 d$ 126, 141 n.9, 496 P.2d 465, 474 n.9, 101 Cal. Rptr. 553, 562 n.9 (1972).

78 See Commitment Following Acquittal, supra note 50, at 935.

79 For a discussion of the magnitude of predicted harm necessary to justify civil commitment, see Developments in the Law, supra note 6, at 1236-38. See also Davy v. Sullivan, 354 F. Supp. 1320, 1330 (M.D. Ala. 1973) (three-judge court), holding that the behavior of an individual convicted of violating a criminal sexual psychopath act must be shown to be dangerous, not merely repugnant, in order to justify long-term commitment.

80 Bolton v. Harris, 395 F.2d 642, 647 (D.C. Cir. 1968); cf. Specht v. Patterson, 386 U.S. 605 (1967); Lynch v. Overholser, 369 U.S. 705, 714 (1962).

81 This confinement is analogous to that provided for in emergency civil commitment situations, with the criminal act as strong evidence of a clear and present danger. See text and note at note 24 supra.

82 See, e.g., In re Franklin, 7 Cal. 3d 126, 143-44, 496 P.2d 465, 475-76, 101 Cal. Rptr. 
ate hearing would allow release of individuals who had committed clearly nondangerous crimes or who had clearly recovered, while permitting commitment of all other individuals.

The procedures for commitment following a not guilty by reason of insanity verdict must also be identical with those for ordinary civil commitment. ${ }^{83}$ The state's strong interest in avoiding errors of underinclusiveness when the individual has committed a crime, however, may arguably justify a standard of proof of dangerousness or incapacity lower than the beyond a reasonable doubt standard of civil commitment. ${ }^{84}$ The United States Court of Appeals for the District of Columbia Circuit has adopted a preponderance of the evidence standard, arguing that the individual should not, after having defeated the government's efforts to prove his sanity beyond a reasonable doubt at one hearing, defeat the subsequent attempt to prove his insanity by producing only enough contradictory evidence to raise a reasonable doubt as to whether he is mentally ill. ${ }^{85}$ But there is no inconsistency in requiring a beyond a reasonable doubt standard at both the trial and the commitment proceeding. Acquittal implies prior mental illness and prior dangerousness. Although the conclusions of the trial court may be relevant to the issues in the commitment proceeding, they should not be given the potentially determinative weight of presumptions about current mental illness and dangerousness. ${ }^{86}$

After commitment, the applicable release standards and procedures for a person found not guilty by reason of insanity must be identical with those for the civilly committed. It might be suggested that a more stringent release standard should apply to this subgroup, ${ }^{87}$ or that the committed individual should be released or provided a full recommitment hearing at the end of the minimum time he would have served as a sentence if he had been convicted. ${ }^{88}$ Both proposals for differential

553, 563-64 (1972) (ninety-day commitment not unreasonable); see also Developments in the Law, supra note 6, at $1280 \mathrm{n} .99$ (collecting various authorities which suggest three to six months as a reasonable period).

83 See Bolton v. Harris, 395 F.2d 642, 651 (D.C. Cir. 1968) (requiring "substantially similar" procedures).

84 See United States v. Brown, 478 F.2d 606 (D.C. Cir. 1973) (2-1 decision).

$.85 \mathrm{Yd}$. at 610 .

$86 I d$. at $613-15$ (Wright, J., dissenting).

87 The argument would be that the individual, having committed a crime, has given stronger evidence of his dangerousness than a civilly committed person, and a higher release standard should therefore be applied to prevent unwarranted release. See, e.g., Omo Rev. CODE ANN. $\$ 2945.39$ (Page Supp. 1974) (requiring a finding that release will not be dangerous and that defendant's sanity has been restored).

88 See United States v. Brown, 478 F.2d 606, 612 (D.C. Cir. 1973); Waite v. Jacobs, 475 F.2d 392, 395 (D.C. Cir. 1973). See also Burt \& Morris, $A$ Proposal for the Abolition of 
treatment ignore the central point: the initial commitment of such an individual is identical with a civil commitment. Although the purposes of purely criminal confinement include deterrence and retribu. tion, for which a predetermined sentence is appropriate, the purposes of commitment after a verdict of not guilty by reason of insanity, even though the dangerous act committed was a criminal act, include only protection of society and treatment of the incompetent individual. ${ }^{89}$ Equal protection therefore requires application of the same statutory release standards and procedures to the not guilty by reason of insanity as to the civilly committed.

Moreover, due process requires that confinement, dependent as it is upon the current status of the individual, continue only as long as the conditions that justified the initial commitment are present. ${ }^{90} \mathrm{~A}$ defendant found not guilty by reason of insanity has as legitimate an interest in maintaining or regaining his liberty as a civilly committed individual, because the verdict is a judgment that the defendant was not sufficiently responsible for his act to warrant application of the penal law. And the state has no additional interest in committing the defendant beyond the interests that justify civil commitment. Thus, the due process balancing test requires the same high level of protection in commitment standards and procedures ${ }^{91}$ for the not guilty by reason of insanity as for the civilly committed, with the exception of a slightly longer prehearing observation period for the former subgroup.

\section{Mentally Ill Criminals}

The final subgroup to be considered in this comment includes persons convicted of criminal offenses but committed to mental institutions in lieu of or during the period of penal incarceration. The Supreme Court has extended most of the protections afforded to the civilly committed to sexual psychopaths ${ }^{92}$ and defective delinquents, ${ }^{93}$

the Incompetency Plea, 40 U. GFr. L. Rev. 66, 74 n.30 (1972) (suggesting that this result follows from the Supreme Court's decisions in Baxistrom and Jackson).

89 See text and notes at notes 54-58 supra.

90 Dixon v. Jacobs, 427 F.2d 589, 595 (D.C. Cir. 1970).

91 See In re Franklin, 7 Cal. 3d 126, 133, 496 P.2d 465, 468, 101 Cal. Rptr. 553, 556 (1972) (full commitment hearing satisfies requirements of due process).

02 In Specht v. Patterson, 386 U.S. 605 (1967), the Court held that the due process clause required full procedural protections in the post-conviction commitment of sexual psychopaths. Later, in Humphrey v. Cady, 405 U.S. 504 (1972), the Court held good a cause of action based on an alleged denial of equal protection in the application of substantially different commitment standards and procedures under civil commitment and sexual psychopath statutes, especially in light of the fact that the choice of which statute applied was arbitrary.

03 In Murel v. Baltimore City Criminal Court, 407 U.S. 355 (1972), the Court indicated 
who are normally committed soon after conviction; ${ }^{94}$ but the constitutional requirements with respect to mentally ill prisoners-those transfered to mental institutions during their imprisonment for criminal offenses-remain unsettled.

Procedural protections for mentally ill prisoners are more abbreviated than those for the civilly committed, ${ }^{95}$ on the ground that subsequent transfer of mentally ill prisoners who have already been deprived of their liberty under the criminal law is not equivalent to a de novo commitment, but is merely a matter of administrative discretion concerning appropriate treatment.96 Two federal courts of appeals have rejected this characterization, holding that the equal protection guarantee requires a civil commitment type hearing with complete procedural protections before involuntary transfer, and application of civil commitment release standards and procedures. ${ }^{97}$ Transferees suffer substantial additional deprivation through increased restrictions, potential psychic harm, potentially longer sentences, and further stigmatization. ${ }^{98}$ This deprivation can be justified only under the same standards that justify involuntary civil commitment, and wrongful deprivation must be avoided through use of the procedures provided by civil commitment statutes. ${ }^{99}$

that commitment standards and procedures for defective delinquents could be judged only by comparison with statutory provisions for civil commitment. The Court dismissed the writ of certiorari in the challenge to Maryland's defective delinquency law as im. providently granted since Maryland's civil commitment laws were under revision. In McNeil v. Director, Patuxent Institution, 407 U.S. 245 (1972), the Court held that under Jackson v. Indiana, 406 U.S. 715 (1972), individuals confined for observation to determine whether they were defective delinquents were denied due process when they were detained indefinitely without procedural safeguards.

94 See ABF STuny, supra note 1, at 345-46.

95 Until the practice was held unconstitutional by the United States Court of Appeals for the Second Circuit, prisoners in New York, for example, were transferred to hospitals for the criminally insane on the certification of one doctor without a hearing or judicial review. United States ex rel. Schuster v. Herold, 410 F.2d 1071, 1080 (2d Cir.), cert. denied, 396 U.S. 847 (1969).

96 See Darey v. Sandritter, 355 F.2d 22, 23 (8th Cir. 1948); People ex rel. Brown v. Johnston, 11 App. Div. 2d 819, 820, 203 N.Y.S.2d 353, 355 (1960).

97 Matthews v. Hardy, 420 F.2d 607, 612 (D.C. Cir. 1969), cert. denied, 397 U.S. 1010 (1970); United States ex rel. Schuster v. Herold, 410 F.2d 1071, 1077-80 (2d Cir.), cert. denied, 396 U.S. 847 (1969).

98 Matthews v. Hardy, 420 F.2d 607, 610-11 (D.C. Cir. 1969); United States ex rel. Schuster v. Herold, 410 F.2d 1071, 1077-80 (2d Cir, 1969); see N. MoRRIs \& G. Hawkins, The Honest Politician's Guide to Crime Control 182 (1970); Morris, Psychiatry and the Dangerous Criminal, 41 S. GAL. L. Rev. 514, 524-25 (1968). See generally Note, Procedural Due Process in the Involuntary Institutional Transfer of Prisoners, 60 VA. L. Rev. 333 (1974). Contra, cases cited note 96 supra.

99 It should be noted that the transfer of mentally ill prisoners for treatment is iden- 
Although an individual's criminal conviction may not justify differences in commitment and release standards and procedures, ${ }^{100}$ it may be relevant in determining the appropriate type of treatment or care. ${ }^{101}$ The analysis is similar to that applied to the not guilty by reason of insanity: because there is no necessary relationship between past dangerous acts and current mental condition or dangerousness, ${ }^{102}$ presumptions as to either condition are invalid in the transfer hearing.

The interests of a prisoner in avoiding unjustified deprivations are similar to those of an individual facing civil commitment, although they may be somewhat less pressing because he has already been deprived of his primary liberties. The state's interests, however, are correspondingly diminished. A prisoner's dangerousness to himself or other inmates can be controlled in the prison with the imposition of fewer restrictions and disadvantages than would be involved in transfer to a mental institution. The only remaining justification for involuntary transfer is the provision of treatment that the prisoner refuses by reason of his diminished competency. The reduced state interest should result in a higher standard for transfer than that required by due process for civil commitment. As long as a substantial deprivation of liberty is involved in involuntary transfers of mentally ill prisoners, ${ }^{103}$ the due process guarantee will require extensive procedural protections to prevent unjustified transfers.

\section{CoNCLUSION}

Despite recent legislative and judicial improvements, disparities and deficiencies continue to exist in the protection provided the various

tical with the commitment of sexual psychopaths, except that transfer may occur after conviction.

100 There are, of course, certain inherent differences, such as the fact that "release" results only in transfer back to prison, Matthews v. Hardy, 420 F.2d 607, 612 n.17 (D.C. Cir. 1969), cert. denied, 397 U.S. 1010 (1970). At the end of the individual's sentence, in contrast with the situation for persons found not guilty by reason of insanity, he must be recommitted (with a full civil commitment proceeding). Baxstrom v. Herold, 383 U.S. 107 (1966).

101 Humphrey v. Cady, 405 U.S. 504, 508 (1972); Baxstrom v. Herold, 983 U.S. 107, 111 (1966); United States ex rel. Schuster v. Herold, 410 F.2d 1071, 1081 (2d Cir.), cert. denied, 396 U.S. 847 (1969); Cameron v. Mullen, 387 F.2d 193, 201 (D.C. Cir. 1967).

102 A presumption concerning this relationship may be even less proper here, where, for example, the mental illness may be senility. The mental illness involved in an insanity acquittal, by contrast, is at least the cause of the original criminal act.

103 It is conceivable that this deprivation could be eliminated by upgrading facilities for the criminally insane, by providing proper treatment, by removing the additional restrictions imposed upon prisoners in these facilities, and by eliminating the lasting stigma by expunging references in the prisoner's record to his transfer for treatment. 
subgroups of the involuntarily committed mentally ill. These inconsistencies are constitutionally impermissible. With the exception of variations in preliminary confinement for observation and specialized treatment, the equal protection guarantee requires identical statutory commitment and release standards and procedures for each subgroup. Furthermore, the due process guarantee requires standards and procedures that will provide substantial protection against unjustified deprivations of liberty.

Susan K. Jackson 